\title{
OBREDI I RITUALI KAO OBLIK STARE JAPANSKE KULTURE
}

\begin{abstract}
U radu se prati razvoj obreda i rituala od njihovog nastanka u ranim predistorijskim periodima (Đomon, Jajoi), do pretvaranja u deo državne strukture sa normativno regulisanim sadržajem (period Kofun). Razvoj rituala prikazuje se kroz formiranje rane državnosti kao deo jedinstvenog procesa. Navode se šinto rituali, a posebno se prikazuju rituali očišćenja.
\end{abstract}

Ključne reči: Japan, obredi, rituali, razvoj rane državnosti, šinto rituali

\section{UVOD}

Koreni japanske kulture nalaze se duboko u praistoriji i vezani su kako za materijalne tako i duhovne izvore. Prvi značajniji materijalni spomenici potiču iz perioda Đomon i vezani su najvećim delom za keramičke predmete, sudove, skulpture, dok su duhovni spomenici, običaji, verovanja sačuvani tek iz kasnijeg perioda. Oni najstariji vremenom su se menjali i u obrađenom obliku stigli do perioda kada su bili zapamćeni. Među najstarijim nematerijalnim spomenicima su obredi, rituali, praznici koji su se održavali pred početak i završetak svakog značajnijeg događaja jer je prvo trebalo odobrovoljiti božanska bića, a na kraju im izraziti zahvalnost. Promene načina života, a posebno proizvodnje hrane imali su značajan uticaj na obrede i rituale, menjajući stare i uvodeći nove. Značajan uticaj imalo je povezivanje religioznih i upravnih funkcija.

U ovom radu se prati razvoj obreda i rituala u periodima Đomon, Jajoi i Kofun kao deo njihovih istorijskih karakteristika. Detaljnije se prikazuju rituali očišćenja, od navođenja u kineskim dinastičkim istorijama i japanskim mitovima, do normativne regulisanosti u periodu rane državnosti. 


\section{ISTORIJSKI PREGLED RAZVOJA RITUALA}

"Neolitska revolucija" kako je engleski arheolog Čajld (Childe 1892-1957) nazvao promenu proizvodnih odnosa, prelazom od sakupljačkog oblika privređivanja na proizvodnu ekonomiju, u osnovi vezanu za zemljoradnju, dovela je u periodu Jajoi, do velikih društvenih i socijalnih promena u Japanu. One su u prvom redu vezane za sedentarni način života pojavom porodičnih zajednica kao zaokruženih ekonomskih celina, promenu socijalne strukture, usled veće proizvodnje hrane i porast uticaja magije da bi se obezbedili bolji prinosi.

Veća proizvodnja hrane, korišćenjem metalnih oruđa i tehnike plavnih polja u proizvodnji pirinča, dovela je do pojave viška vrednosti i početka društvenog raslojavanja. Dolazi do stvaranja seoskih zajednica kada se više porodičnih zajednica udružuje, po raznim pitanjima, posebno u zajedničkom sprovođenju molitvenih praznika i rituala u toku cele godine. To nije bila svesna pripadnost određenoj religiji, koja još nije postojala jer verska strana života još nije bila odvojena od društvenog i ekonomskog: svi aspekti života bili su tada u nerazdvojenom jedinstvu. Imovinska diferencijacija počinje kada se izdvaja grupa ljudi (uglavnom starešine zajednica) koja je imala mogućnost sakupljanja i raspolaganja viškom proizvoda.

Nemoć ljudi pred prirodnim silama od kojih je zavisila letina, povećavala je uticaj magije i dovela je do pojave različitih obreda i rituala, karakterističnih za agrarni kult da se stvore uslovi pogodni za nicanje, rast i sazrevanje poljoprivrednih useva. U seoskim zajednicama postali su obavezni obredi čiji je cilj bio da uz pomoć magijskih rituala garantuju uspešnu obradu zemlje i bogatu žetvu (Saburo,1972: str 31).

U početku, bili su samo obredi koji su obuhvatali "rasterivanje" zlih sila koršćenjem magije reči, da bi se kasnije, kao rituali, orijentisali na obraćanja božanskim bićima kada su ljudi, verujući u duh reči (kotodama), ritualnim molitvama (norito), igrom i pesmom, molili bogove da im daruju dobar rod.

Uzajamna veza društvene, ekonomske i verske oblasti života postepeno je prerasla u složeniji kulturni model, u kome su se pojedine porodice uzdigle posedovanjem više zemlje i raspolaganjem većim materijalnim vrednostima. Na početku nove ere, kada je japanska kultura već dostigla dovoljno visok nivo razvoja, počinje da se oseća uticaj kulture kontinentalne Azije (Earhart, 1996, 512). 
Postepeno, od postojećih kolektivnih društvenih, ekonomskih i religijskih odnosa stvara se znatno centralizovanija i organizovanija nacionalna struktura, od tada poznata pod imenom Jamato. Osobina koja je karakterisala novonastalu nacionalnu zajednicu postala je poštovanje prema jedinom vladajućem rodu, koji je dobio status carske loze, a čije poreklo je bilo vezano za boginju Sunca, dok su rituali postali deo šinto ceremonija koji su propisane normativno i vezivane su za poljoprivredne radove, praznike hramova i posebno, carsku porodicu.

\section{PERIOD ĐOMON}

Đomon je period japanskog neolita, mlađeg kamenog doba (od 13000 - 8000 god pre n.e do 300 god n.e.), za koji postoje samo materijalni, arheološki spomenici, na osnovu kojih se zaključuje o svim relevantnim saznanjima vezanim za taj period, kako proizvodnim i društvenim tako i kulturnim i religioznim. Zato je potrebno razmatrati raspoložive arheološke nalaze da bi izdvojili one koji se mogu povezati sa religioznim saznanjima (obredima i ritualima) (zbog čega prikazujemo osnovne podatke o arheološkim nalazima).

Period Đomon je bio ravnomerno zastupljen na celoj teritoriji Japana (Жуков, 1998: 30). Dok je u centralnom delu trajao kasni neolit, na jugu je već bilo bronzano i gvozdeno doba (Kidder, 2003: 25). Ljudi su živeli u plemenskim zajednicama od lova i ribolova i sakupljanja prirodnih plodova. Po rečima japanskog arheologa Vatanabea "lovili su sve što se moglo uhvatiti" (Marković, Jovic, 2008: 29). O periodu Đomon ostalo je malo podataka izuzev ručno rađene keramike, ukrašene tragom konopca utisnutog u vlažnu glinu, što predstavlja glavnu karakteristiku ovog perioda. Krajem perioda počelo je gajenja pirinča bez navodnjavanja, tehnikom suvih polja, što je bio razlog početka stalnije naseljenosti.

O kulturi i verovanjima perioda Đomon i Jajoi nema neposrednih, izvornih podataka tako da se o njima zaključuje indirektno, na osnovu arheoloških materijala i paralela sa drugim starijim kulturama u regionu. $\mathrm{Na}$ osnovu toga se pretpostavlja da je kultura perioda Đomon (i kasnijeg dela perioda Jajoi i ranog Kofuna) imala elemente animizma, dok su pojedini arheološki nalazi pokazali elemente totemizma (Brown, 2008: 358).

Macumae Takeši navodi (Brown, 2008: 325) da su se u periodima Đomon-Jajoi koreni kulture i ranog šinta razvijali iz animističkih oblika obožavanja prirode. U ovom periodu ljudi su poštovali duhove planina, 
polja i potoka u blizini svojih naselja, a mitovi su bili vezani za prirodu i poreklo najznačajnijih osobina iz okruženja. Ljudi ovog perioda razvili su magijske obrede sa ciljem da im pomognu u lovu, ribolovu i poljoprivredi, pa je svaki posao počinjao i završavao se obredima.

U toku kasnijeg perioda, koji prema Macumaeu (ibid.) obuhvata IV i V vek i dva naredna veka države Jamato, animistički duhovi bili su personifikovani i prerasli su u božanska bića - kamije, posebno poštovane duhove sa velikom snagom i mogućnostima.

Izvor religioznih saznanja u periodu Đomon predstavlja i materijal nađen u grobnicama. Njegovo prisustvo ukazuje da su ljudi verovali u postojanje duše i zagrobni život. Sastav takvog inventara su stvari koje su korišćene za života: češljevi, minđuše, narukvice, nakit, prstenje i pojas.

Još jedan artefakt vezan sa religioznim saznanjima ljudi perioda Đomon su keramičke ženske figure - $d o g u$. Pretpostavlja se da dogu simboliše ženski element, porodicu, rađanje. Korišćeni su u obredima vezanim za kult plodnosti. Sa istim kultom asociraju se i falusni sumboli: kamene sekire - sekibo, kameni mačevi i noževi, koji simbolišu muški element, vlast i autoritet.

Keiđi Imamura navodi da su se $d o g u$ figure koristile u ritualima sa ranjenim ili bolesnim ljudima, zbog čega su, kod većine nađenih figura, udovi polomljeni (Imamura, 1996: 96). Pored toga, nađeni su i artefakti iz kasnog perioda Đomon za koje se smatra da pojačavaju ritualne funkcije. Osim keramičkih i kamenih figura to su keramičke maske, kameni štapovi, kamene ploče sa šarama (Imamura, 1996: 119). U završnom delu perioda Đomon broj ritualnih predmeta se smanjuje, tako da nestaju sa pojavom zemljoradnje u periodu Jajoi usled promena koje su pratile promenu uslova i načina života (Imamura, 1996: 120).

\section{PERIOD JAJOI}

Period Jajoi (300 god pre n.e.-250-300 god n.e.) je prelazni period između kamenog i metalnog doba, odnosno vreme u kome su istovremeno postojala kamena, bronzana i gvozdena oruđa. Početak ovog perioda vezan je za pojavu nove kulture, verovatno kontinetalnog porekla. Njene odlike bile su gajenje pirinča tehnikom plavnih polja, korišćenje grnčarskog točka i razboja, obrada metala (bakra, bronze i gvožđa) i gradnja zaštićenih naselja.

Početak gajenja pirinča tehnikom plavnih polja imao je ogroman uticaj na japansko društvo izmenivši celu njegovu strukturu. Ljudi su počeli 
da se koncentrišu u naseljima. Pojavila se mogućnost sakupljanja viška proizvoda čime je počeo da se stvara sistem klasnih odnosa. Stvorena je nova društvena struktura - zemljoradnička zajednica, koja je predstavljala proizvodnu celinu koja je bila osnova za jače plemensko udruživanje, stvaranje plemenskih saveza i kasnije formiranje državne organizacije (Jovic Đalović, 2008: 129).

Keiđi Imamura, (Imamura, 1996: 197), smatra da su period Jajoi obeležila četiri sledeća glavna događaja:

1. Početak razvoja poljoprivrede zavisi najvećim delom od prinosa pirinča na plavnim poljima.

2. Nabavka i proizvodnja bronzanog i gvozdenog alata.

3. Aktivna razmena sa Korejom i Kinom uključujući migracije, trgovinu i diplomatske odnose.

4. Početak društvenog raslojavanja i pojava političkih tela koji se kasnije ujedinjuju u državu.

Za razliku od kulture perioda Đomon, kultura Jajoi nije se proširila na teritorije juga ostrva Kjušu, severa ostrva Honšu, ostrva Hokaido i Okinavu (Мещеряков, 2010: 62).

Religiozni život imao je u to vreme, po pretpostavkama istraživača, šamanistički karakter i na raniju, horizontalnu kosmologiju perioda Đomon, kada su bogovi i duhovi dolazili preko mora, iza horizonta, postavljena je vertikalna osa šamanskog sveta. Pošto se u centru privrednih, aktivnosti našlo gajenje pirinča tehnikom plavnih polja, verska aktivnost takođe je bila vezana za obrede plodnosti i prinosa letine (Smirnov, 2010: 51). Na osnovu mitova sastavljenih znatno kasnije, ali koji, kako se pretpostavlja, sadrže postupke iz ranijeg perioda, ovi obredi se imaju sličnosti sa praznicima u Jugo-istočnoj Aziji u oblastima Indonezije (Kumar, 1998: 265-276).

Vezivanje osnovne proizvodne grane za zemljoradnju, koja znatno zavisi od spoljašnjih uslova - prirode, klime, na koje čovek nije mogao da utiče, povećavalo je potrebu za magijom. Tako su u seoskim zajednicama postali obavezni različiti obredi čiji je cilj bio da uz pomoć magijskih rituala garantuju uspešnu obradu zemlje i prikupljanje bogate žetve. Stoga nije slučajno da su šamani koji su vršili magijske rituale imali istovremeno važnu ulogu u upravljanju seoskim zajednicama (Saburo, 1972: 31).

Migranti koji su preneli tehnike gajenja pirinča, doneli su rituale i običaje vezane za poljoprivredu. Priređivane su svetkovine u pojedinim 
fazama poljoprivrednih radova (matsuri), da bi pozvali ili umirili lokalne duhove (božanstva). Bitni elementi ovih praznika predstavljaju razni oblici izražavanja poštovanja duhu pirinča i duhu hrane. Smatra se da su koristili i bronzana zvona (dotaku) da bi prizvali duhove pirinča, zemlje, a moguće i duhove predaka. Ritualne molitve (norito) koje su bile osnovni deo ovih svečanosti, ukazuju na prvobitna agrarna verovanja određujući kamija hrane Tojukea (Toyouke Okami) kao duha pirinča. On ima još jedno ime - Ukanomitama, ime koje se bukvalno prevodi kao "duh hrane" (Brown, 2008: 332).

Na bronzanim zvonama nalaze se likovi raznih životinja. Ajlin Kavago smatra da je najverovatnije da su ove životinje (jeleni, ribe, ptice, žabe, gušteri, kornjače, psi, zmije, pauci krabe) bile lokalna božanstva, koja su u to vreme poštovali ljudi iz perioda Jajoi i podnosili im darove. Arheolozi smatraju da su jeleni predstavljali duhove plodnosti zemlje , čaplje i ždralovi duhove pirinča.

Period Jajoi je prvi period japanske istorije o kome postoje pisana dokumenta. To su materijali kineskog porekla: Han shu, kompletiran oko 82 godine, Wei chih, kompletiran u trećem veku (Tsunoda, Carrington 1951: 1-16).

Najraniji materijal o Japanu nalazi se u "Han Šu" (Han Shu), Istoriji Rane (Zapadne) dinastije Han (206. godine pre nove ere 8. godine nove ere). U ovoj kineskoj dinastičkoj istoriji nalazi se prvo pominjanje Japana kao zemlje istočnih varvara Va. U Istoriji Kasne (Istočne) dinastije Han "Hou Han Šu" (Hou-Han-Shu 25-220 godine) ima više informacija o odnosima sa Japanom u I-II v. n. e. Najpotpuniji je treći kineski spomenik "Vei Ći" (Wei chih), Istorija kraljevstva Vei, koje je postojalo u Kini u III veku n. e. (221-265 godine). U ovoj hronici postoji posebno poglavlje o ljudima Va tj. o Japancima. To je najpotpuniji pregled Japana koji postoji u kineskim izvorima i za koji se smatra da je istorijski pouzdan. Dalje hronološki slede "Sung-shu", istorija kraljevstva Sung, koje je postojalo u Kini u V veku. "Istorija kraljevstva Sung" sadrži pominjanje Japana u V veku. Na taj način, kineski izvori daju podatke o Japanu, počev od I veka pre nove ere do V veka nove ere (Konrad, 1937: 2).

Za ovaj period je značajna i pojava plemenske organizacije. Plemena su se međusobno borila, a u toku tih borbi dolazilo je do mešanja plemena i stvaranja savremenog oblika Japanaca, produbljivalo se raspadanje poretka prvobitne zajednice, stvarao se sloj imućnijih članova zajednice koji su 
bili na čelu velikih porodičnih grupacija, formirala se japanska narodnost. $\mathrm{U}$ toku ove borbe formiran je plemenski savez, koji se pominje u kineskoj dinastičkoj hronici "Istorija kraljevstva Vei" (Wei chih), na čelu koga je bila kraljica Himiko. Period vladavine Himiko bio je približno od 173250. godine n.e. Plemenski savez Jamatai (Yamatai) nalazio se ili na ostrvu Kjušu ili na ostrvu Honšu (Кузнецов и др, 1988: 19).

\section{PERIOD KOFUN}

Period Kofun dobio je ime po velikim nasutim grobnicama (kofun) u kojima su tokom III-VII veka, sahranjivani predstavnici plemstva. U ovom periodu stvara se drugi plemenski savez koji će prerasti u prvu japansku državu Jamato (Yamato), zbog čega ga pojedini naučnici nazivaju period Jamato. U ovom periodu dolazi do jačanja ekonomske moći, pojave klasa u društvu, uzdizanja Jamato dvora, početne urbanizacije (izgradnja prestonice) i usvajanje budizma sa azijskog kontinenta.

Termin "kofun" označava ne samo "tumulus", već potpuno određeni sistem sahrane, koja je evoluirala tokom vremena. Postoje "kružni " i "kvadratni" tumulusi, kao i razne njihove modifikacije, ali se kao poseban, "japanski" tip, smatra "kvadratno-kružni" (tumulus u obliku ključaonice).

Sve najveće humke imaju upravo takvu formu što se može smatrati dokazom proširenosti takve konfiguracije. Ovaj tip tumulusa prvi put se pojavljuje u oblasti ravnice Nara u početku IV veku, a zatim se širi i na druge oblasti Japanu, što naučnici smatraju indikatorom uvlačenja novih teritorija u politički i kulturni uticaj države Jamato.

Najviše nasutih grobnica ima u oblastima Kinai, Osaka i Nara, a za najveće, u oblasti Kinai, veruje se da su mesta na kojima su sahranjeni carevi Suđun, Nintoku i Ođin, pri čemu je najveća bila grobnica cara Nintokua dužine $486 \mathrm{~m}$ površine $300.000 \mathrm{~m}^{2}$ (Marković, Jović, 2008: 161).

Japanski naučnici dele period Kofun na dva ili tri potperioda: rani (4. vek), srednji (5. vek) i kasni (6. i 7. vek); ili rani (IV i V vek) i kasni (6. i 7. vek). Mi ćemo se u ovom radu pridržavati trodelne podele (Barnes, 2007: 8) i trajanja perioda od 250. (300.) do 710. godine tako da obuhvata i period Asuka, kao kasni potperiod Kofun.

Period ranog Kofuna karakteriše ritualizovan autoritet plemenskih vođa koji i dalje obavljanjaju verske funkcije spajajući svetovnu i versku vlast. U pogrebnom materijalu nađenom u grobnicama, pored oružja, ličnih ukrasa i drugih stvari praktične namene, nađeno je i mnogo predmeta 
koji su se koristili za vođenje verskih obreda: bronzana ogledala, narukvice od jaspisa i drugi kultni predmeti od jaspisa. Centar političke moći bio je u to vreme u području Miva, jugoistočnog dela basena Nara, uključujući i okrug Makimuku u kojem se nalazi grobnica Hašihaka - u kojoj se smatra da je sahranjena kraljica Himiko (Barnes, 2007: 10).

U srednjem delu perioda Kofun, plemenske starešine nastupaju kao političke vođe, oslobodivši se potpuno verskih obaveza. U pogrebnom materijalu umesto predmeta koju mogli imati versku funkciju povećava se broj predmeta sa svetovnom ulogom. Ако su do tada verske obrede vodile starešine klanova koji su čuvali dragocene obredne predmete, to se sada javljaju drugi, obični ljudi koji su počeli da obavljaju formalne obrede koristeći za to imitacije kultnih predmeta (Чан Су Бу, 1988: 128).

Ovaj deo potperioda Kofun obeležen izgradnjom veoma velikih grobnica u obliku ključaonice na ravnici Osaka. Sadržaj grobnice pretrpeo je značajne promene: bronzana ogledala i fini proizvodi od perli više nisu odlagani. Umesto toga, bilo je više gvožđa u obliku oklopa, oružja i alata (Barnes 2006a). Konjski pribor, keramika tipa Sue, pozlaćeni bronzani nakit i zlatni nakit počeli su da se pojavljuju u većim količinama sredinom V veka. Menjao se oblik sarkofaga. Postajali su veći i kitnjastiji. Ovaj potperiod se poklapa sa vladavinom careva dinastije Ođin i dvora Kavaći (Barnes, 2007:10).

Kasni potperiod Kofun poklapa se sa periodom Asuka (592-710 godine). Tada se sve ređe javljaju veći pravougaoni i okrugli tumuli, ali se naglo povećava broj manjih, koji se grade u većim grupama, na malom međusobnom rastojanju. To više nisu bile grobnice vođa klanova kojih nije bilo mnogo, već činovnika kojih je bilo znatno više. Pri tome, ovaj oblik sahranjivanja nije obuhvatao obične ljude.

Izgradnja grandioznih grobnica bila je moguća samo pri postojanju solidnog znanja iz oblasti građevinarstva, dovoljno razvijenim alatima za rad i sistem koji može da mobiliše ogromnu radnu snagu. Svi ovi preduslovi bili su stvoreni u prethodnom periodu Jajoi. Pojava običaja sahranjivanja u nasutim grobnicama i njegovo širenje bili su tesno povezani sa uspostavljanjem vlasti Jamato dvora i širenjem uticaja u celoj zemlji.

\section{DRŽAVA JAMATO}

Prva japanska država Jamato javlja se u kasnom potperiodu Kofun i o njenom stvaranju ne postoje pisani istorijski izvori. Kineske dinastičke 
istorije potvrđuju da se u periodu Kofun vodila plemenska borba zbog koje se smanjivao broj plemena. Prema hronici Han Shu, na početku naše ere u zemlji Va je bilo više od 100 država, dok je, prema hronici Wei chih u III veku ostalo oko 30 država (Воробьев, 1958: 69).

Konrad navodi da se kao rezultat žestokih međusobnih borbi pojedinih klanova, početkom II veka inicira proces ujedinjenja i stvaranja plemenskog saveza u oblasti Kinai na mestu glavne koncentracije plemena Jamato. Ovaj integracioni proces verovatno u III veku dovodi do saveza više plemena i formiranja sredinom IV veka drugog plemenskog saveza u centru ostrva Honšu (Конрад, 1935: Лекция 06). Na čelu saveza, koji je kasnije prerastao u državu Jamato nalazio se klan Sumeragi, koji je objedinio svetovnu i duhovnu vlast.

U VI i VII veku Jamato dvor je jakim klanovima u provincijama postepeno smanjivao svetovnu vlast i nadležnosti u upravljanju magijsko-religijskim aktivnostima. Klanovi su formirali dvorsku aristokratiju u srodstvu sa carskim klanom, njihove tradicije su usvojene od strane carske porodice i korišćene za jačanje položaja cara. Boginja Sunca, Amaterasu bila je prihvaćena kao predak carske porodice i dodeljen joj je najviši položaj u panteonu. Na taj način, uočava se početak organizacije i sistematizacije šintoizma na državnom nivou.

Preuzimanje vrhovne religijske vlasti od strane Jamato dvora bio je postepeni proces, koji je obuhvatao asimiliranje lokalnih ceremonija, mitova, sakralnih vrednosti i kamija. Ovaj proces se može videti poređenjem običaja i mitova između Jamato i drugih provincija. Za početak, jaki lokalni klanovi ojačali su veze između svojih sveštenih i svetovnih funkcija. Oni koji su preuzeli religijsku vlast monopolišući obožavanje značajnog kamija počeli su neke od svojih predaka da poštuju kao kamije. Kombinovali su svetovnu i religijsku vlast kao neku vrstu "svetog kraljevstva" koje je potvrđeno posedovanjem regalija i periodičnim ponavljanjima rituala. Neki od ovih rituala se izvode i danas, iako su sveštenici izgubili prava na vršenje tih obreda pre više od milenijuma (Brown 2008: 342).

Pošto je carski klan bio u vojničkom pogledu jači od drugih, to je još u početku istorijskog doba počeo da ih podčinjava svom političkom i verskog uticaju. Ujedinjenje Japana pod klanom Sumeragi pratila je sistematizacja verske prakse i mitova svih klanova koji su ušli u njen sastav. U njihovom životu sada se osetilo prisustvo "nacionalnog kamija" tj. kamija klana Sumeragi (Kitagawa, 2005: 30). 
Proglašavanjem boginje sunca Amaterasu za pretka carskog klana Sumeragi i dajući lokalnim ritualima i ceremonijama organizovaniji karakter prevodeći ih na nivo državnih, postavljen je temelj daljem stvaranju japanske nacionalne državnosti.

\section{ŠINTO RITUALI}

Šinto rituali su način komunikacije sa kamijima (duhovi - bogovi, koji postoje u svakom predmetu). Nastali su u najstarije vreme i bili su ili jednostrani, od čoveka ka kamijima, kada su se ljudi obraćali kamijima, izražavali im zahvalnost, tražili pomoć, ili dvostrani, od čoveka ka kamijima i od kamija ka čoveku, kada su ljudi želeli da dobiju odgovore na važna pitanja ili da saznaju rešenja svojih životnih problema. U tom slučaju postojao je posrednik, medijum ili svešteno lice, koji je prenosio odgovore kamija.

Smatralo se da kamiji prenose na ljude sposobnost i umeće da obavljaju određene poslove ili da sami kami preko ljudi obavljaju poslove korisne za ljude i zato je trebalo ritualima stalno komunicirati sa njima, moliti im se, pre otpočinjanja svakog posla, da omoguće uspešan rad, a po završetku, izražavali su im zahvalnost. Kroz rituale ljudi su želeli da utiču na kamije, na prirodne stihije i da održavaju harmoniju sa prirodom. U njima su dostizali osećaj jedinstva i spajanja sa prirodom, osećali ritam prirode i aktivnosti kamija.

Ritualni obredi praćeni su igrom, pesmom, muzikom, izgovaranjem molitvenih tekstova (norito), koji su pojačavali vezu između ljudi i božanstava dok se kroz mnogo mističnih elemenata, uzdizala veličina kamija. Iz ovih neobaveznih obreda i verovanja postepeno su se stvarali obavezujući obredi koji su se pretvorili u religioznu celinu, koju Kitagava naziva "rani šinto", odnosno šinto pre budizma i kineske filozofije. On navodi da u to vreme nije bilo kanonizovane liturgije, religijske organizacije ili detaljno razvijenih rituala. Većina religioznih obreda, osim kućnih, vršena su oko svetog drveta (himorogi), svetog kamena (ivasaka) a kasnije, sa pojavom zemljoradnje, i na pirinčanim poljima (Kitagawa, 2005:23-25).

Razmatrajući poreklo šinto rituala američki naučnik, prof. Dž. Kitagava navodi da stare Japance nije brinuo moralni greh već fizičko i mentalno zaprljanje, od koga su morali da se oslobode isterivanjem i uzdržavanjem. Mada jedna ritualna molitva (norito) pominje dve kategorije greha 
(Phillippi 1990:44-46): smatralo se da su uzrok greha (tsumi) ili zla (ashi) prvenstveno bili spoljni faktori. Kao rezultat toga, nije se smatralo da zlo postoji objektivno, kao realni objekat, već se pre vezivalo za nedostatak harmonije i lepote, a čovek se ceremonijama pročišćenja (harae) mogao ispraviti i promeniti čim je izvršio egzorcizam (Китагава, 2005:25-26).

Japanski naučnici Okada Seiđi i Macumae Takeši, razmatrajući korene rituala povukli su paralele između mitova i obreda koji su vršeni na dvoru prve japanske države Jamato, a koji su kasnije ušli u kodekse Joro i Engišiki. U svojim radovima oni navoda sledeće paralele (Ермакова, 1997:36-37):

1. Mit o stvaranju japanskih ostrva - obred Osam velikih ostrva ( $\mathrm{Ya}$ soshima no matsuri); ovaj ritual je verovatno prethodio Ceremoniji Velike probe nove žetve (Ōnie no matsuri) i bila osnova za ceremoniju uvođenja na presto;

2. Mit o rađanju boga vatre - obred umirivanja vatre (Hi shijume no matsuri);

3. Umivanje Izanagi na obali - obred gozbi na putevima (Michiae no matsuri);

4. Epizoda vezana za boravak boginje Amaterasu u prostoriji za tkanje, koji prethodi njenom skrivanju u Nebeskoj pećini - obred tkanja odeće za bogove (Kami miso no matsuri) u hramu Ise;

5. Mit o povlačenju boginje Amaterasu u Nebesku pećinu - ritual prenosa Ise hramova u pojedinim vremenskim periodima sa jednog na drugo mesto;

6. Igra boginje Ame-no-uzume - ritual umirenja duše [imperatora] (Tamashizume no matsuri);

7. Proterivanje Susanoa sa Ravnine visokog neba - ritual velikog isterivanja nečistoće (Ōharai);

8. Silazak Nebeskog unuka Ninigija sa neba na zemlju - uvodni ritual ustoličenja na presto, vezan za početak nove godine;

9. Pripovedanje o poseti dvorca morskog cara iz mitova Kjušu obred služenja bogova i proba plodova nove žetve (Niiname no matsuri) i mesečni noćni obredi gošćenja bogova.

Rani carski dvor autorizovao je četiri porodice. Jedna porodica bila je zadužena za rituale i ceremonije. Druga je dobila zaduženje da očuva ritualnu čistotu i bude u neprestanom kontaktu sa kamijima. Treća porodica bila je odgovorna da spozna volju kamija, a članovi četvrte porodice 
bili su plesači i muzičari. Samo mali broj ceremonija izvodio je sam car, i u najvećem delu, šinto obredi bill su povereni ovim porodicama. Od šinto sveštenika se nije zahtevao celibat. Molitve i rituali prenošeni su sa oca na sina, sa generacije na generaciju (Hare, 2002: 76).

\section{OBREDI PROČIŠĆENJA}

Obred pročišćenja je jedan od najstarijih šinto rituala i vezan je za uklanjanje svake nečistoće i oslobađanje grehova. Prva svedočenja o obredima nalazimo u kineskoj dinastičkoj hronici "Istoriji kraljevstva Vei" (Wei Chih oko 297. godine): "Kada neko umre... glavne narikače plaču i zapevaju, a ostali rođaci igraju, pevaju i piju alkoholno piće. Po završetku sahrane, svi članovi porodice obavljaju ritualno očišćenje u vodi" (Tsunoda, Goodrich, 1951: 11).

U japanskoj mitologiji pojam nečistoće vezan je za mit o zaprljanju Izanagija u zemlji mraka Jominokuni, čime se uvodi da nečistoća potiče iz dodira sa drugim svetom ${ }^{1}$. Izanagi se posle povratka čistio nekoliko puta pranjem lica i celog tela. Ovo je poslužilo kao podloga uvođenju obreda prećišćavanja: harae, misogi, oharae, šubacu (shubatsu).

\section{HARAE}

Harae je egzorcizam, odnosno postupak mentalnog čišćenja, odbacivanja svih loših misli i osećanja. Čišćenje vrši sveštenik i ritual isterivanja zagađenja obuhvata molitvu, mahanje palicom za pročišćenje (heihaku) i često, posipanje soli ili slane vode, koji imaju moć pročišćenja. Najveća zagađenja donose dodir sa mrtvom osobom i krvlju (Sansom 1938, 50-51).

\section{MISOGI}

Misogi je obred očišćenja predviđen za otklanjanje nečistoće dobijene slučajnim dodirom sa nečistim stvarima - od prostog zagađenja do zagađenja usled bolesti i smrti. Vrši se pranjem celog tela u vodi protočnoj ili stajaćoj sa ili bez soli. Postoji više postupaka za izvođenje ovog rituala. Ovaj obred je izvodio Izanagi (Sansom, Ibid).

\section{OHARAE}

Obred predstavlja istovremeno očišćenje većeg broja ljudi. Njegov

1 Prvo pisano pominjanje zaprljanja od smrti, značajno i za savremenu kulturu, nalazi se u prvom svitku Nihon Shoki: “Ako u kući neko umre na vrata se stavlja natpis sa značenjem «tabu», «zabrana» i stanovnici u toku godinu dana ne smeju da ulaze u šinto hram, pošto su bili u dodiru sa nečistoćom" (Нихон Сёки $\urcorner$ Анналы Японии (свитки $\mathrm{I} \neg \mathrm{XVI}$ ) стр. 410, primedba 70). 
cilj bio je da se spreči katastrofa čišćenjem sebe od greha i zagađivača (kegare) koji su se nesvesno zaprljali. U Odeljenju Zemaljskih i Nebeskih božanstava (Jingikan) opisana su dva oblika velikog pročišćenja oharae. Prvi je uobičajeni dvogodišnji obred koji je poslednjeg dana šestog i dvanaestog meseca vršio Car, pred svim zvaničnicima i članovima njihovih porodica u dvorištu. Drugi je poseban obred, koji se mora izvršiti po potrebi u različitim provincijama. Takođe se sprovodi na posebnoj osnovi u dvorištu kada je neko postao ritualno nečist ili nesvesno počinio bilo kakav zločin (Смирнов, 2010: 152).

Sansom navodi da su među sačuvanim starim rukopisima nalaze i opisi obreda "Veliko pročišćenje" i "Molitve za žetvu", koje sadrže najstarije verske predstave japanskog naroda i koji po svoj prilici potiču iz ranih faza plemenskog života. Prvi od ovih dokumenata odražava duboki smisao ritualne čistoće, a zasniva se na potrebi da se izbegavaju postupci koji prljaju, pre svega telo, ali samim tim i duh. Drugi je prožet velikom zabrinutošću u vezi s obezbeđenjem hrane i otkriva stavove vladajuće klase o značaju poljoprivrede za državu.

Obred velikog pročišćenja, bez obzira na to što sačuvani tekstovi potiču iz IX veka, svakako sadrži podatke iz najstarijih vremena. Obred je obavljan na carskom dvoru, u prisustvu prinčeva, plemića i svih ministara, sekretara, visokih činovnika i gradskih zvaničnika, kako civilnih tako i vojnih. Svrha tog obreda bilo je pročišćenje cele nacije od grehova koji su namerno ili nenamerno bili počinjeni ili mogli da budu počinjeni, što se postizalo molitvom i prinošenjem darova. Veoma je zanimljiv spisak nebeskih i zemaljskih grehova, koji se čita tokom molitve. Nebeski grehovi uopšteno se pripisuju naprasitom bogu Susanou koji se u mitu o dobu bogova pojavljuje kao neka vrsta izazivača nereda. Reč je o gresima koji su se posebno osuđivali u agrarnom društvu, budući da se radilo o postupcima koji su ugrožavali snabdevanje hranom - recimo, zatrpavanju kanala za navodnjavanje i sejanju kukolja - ili pak okajanju obredne čistoće time što su nečasnim radnjama zagadili sopstveni dom. Ovi gresi nazivali su se "nebeskim“" stoga što su se posebno odnosili na bogove koji su odlučivali o sudbini naroda. "Zemaljski“" gresi podrazumevali su remećenje društvenog poretka, postupke koji su bili gnusni zato što su uticali na dobrobit članova zajednice. Ovo je uključivalo ubistva i ranjavanja, incest, sodomiju, veštičarenje, čarobnjaštvo i sramotne bolesti, kao uzroke zagađenja i skrnavljenja pre nego kršenje moralnog zakona (Sansom, 1958: 79). 


\section{ZAKLJUČAK}

Obredi i rituali bili su od ranijih perioda deo vlasti, način održavanja jedinstva plemena i obezbeđenja njegove budućnosti i u osnovi su bili vezani za tri ključne stvari: zemljoradnju, sile prirode i kult predaka. U najranijim periodima Đomon i Jajoi, osnovni cilj svih obreda bio je dobijanje obilne žetve, a komuniciranje sa prirodom i precima trebalo je da umilostivi duše predaka da pomognu da se dobije i očuva žetva. U potperiodima ranog i srednjeg Kofuna obredi i rituali, pored obreda obezbeđivanje hrane, obuhvatali su i obrede sahranjivanja. U kasnom potperiodu Kofun stvara se sistem verovanja, kasnije nazvan šinto, koji dalje razvija prihvaćene obrede i rituale dopunjujući ih odgovarajućim za dobrobit carske porodice.

\section{LITERATURA}

Brown D.M. ed, (1993) "The Cambridge History of Japan", Vol. 1, Ancient Japan", Cambridge University Press,

Encyclopidia of Shinto http://eos.kokugakuin. ac.jp [27.12.2018.]

Gina L. Barnes (2007) "State Formation in Japan, Emergence of a 4th-century ruling elite", Routledge New York

Hare Paula (2002) "Šinto", Čigoja Beograd

Imamura Keiji (1996) "Prehistoric Japan: New Perspectives on Insular East Asia" University of Hawaii Press, Honolulu

Jović Đalović M.(2014) "Osnovne karakteristike razvojnog puta japanske kulture u periodima Jomon i Yayoi" Zbornik Filološka istraživanja danas Kultura, civilizacija, filologija, Beograd

Kumar Ann (1998) "An Indonesian Component in the Yayoi?: The Evidence of Biological Anthropology", Anthropological

Science 106

Marković Lj. Jović M. (2003) "Istorija japanske civilizacije; Od početka do perioda Nara" Kokoro, Beograd

Philippi, D.L. (1990). "Norito -A translation of the ancient Japanese ritual prayers". New Jersey: Princeton Univ. Press

Sansom G.B. (1937) "Japan - A short cultural history", Stanford University Press Tsunoda R, Carrington Goodrich L. (1951) "Japan in Chinese dynastic histories", Perkins, South Pasadena

Воробьёв М.В. (1958) "Древняя Япония" Москва., Издательство восточной литературы 
Ермакова Л.М. (1997)“Нихон-сёки” - культурный полицентризм и выбор культуры // Нихон-сёки: Анналы Японии, Гиперион, СПб.

Жуков А.Е. ред. (1998) "История Японии том I, Од древнейших времен до 1868 г.",РАН Москва

Иэрхарт Б. Г. сост, (1996), “Религиозные традиции мира”, том 2, КРОНПРЕСС, Москва

Киддер Дж. Э, (2003), Япония до буддизма : Острова, засел. богами, Москва, Центрполиграф

Китагава Дж.М. (2005) "Религия в истрии Японии" Санкт-Петербург , Наука

Конрад Н.И. (1937) "Лекции по истории Японии (1936/1937 уч. год.)". Моск. инст. Востоковедения. Москва

Кузнецов Ю.Д., Навлицкая Г.Б., Сырницкий И.М. (1988) “История Японии”, Москва

Мещеряков А., Грачев М. (2010) "История древней Японии", Наталис, Москва

Сабуро И. (1972) “История японской культуры”, Прогресс, Москва

Смирнов И.С., ред (2010) "Энциклопедия Синто" Москва

Чан Су Бу (1988) "Период кофун в Японии" Очерки тихоокеанской археологии. Владивосто

\section{Marina V. Jović Đalović}

RITES AND RITUALS AS FORM OF EARLY JAPANESE CULTURE

\section{Summary}

The work deals with the development of rites and rituals since their emergence in the early prehistoric periods (Jomon, Yayoi) becoming part of the state structure with normatively regulated content (Kofun period). The development of the rituals is shown through the formation of early statehood as part of a unique process. Shinto rituals are listed, and in particular rituals of purification are shown. rituals

Key words: Japan, rites, rituals, development of early statehood, Shinto 